Stern, Julian ORCID:

https://orcid.org/0000-0003-4126-0100 and Shillitoe, Rachael (2019) Prayer Spaces in Schools: A Subversion of Policy Implementation? Journal of Beliefs and Values.

Downloaded from: http://ray.yorksj.ac.uk/id/eprint/3765/

The version presented here may differ from the published version or version of record. If you intend to cite from the work you are advised to consult the publisher's version: https://www.tandfonline.com/doi/full/10.1080/13617672.2019.1596046

Research at York St John (RaY) is an institutional repository. It supports the principles of open access by making the research outputs of the University available in digital form. Copyright of the items stored in RaY reside with the authors and/or other copyright owners. Users may access full text items free of charge, and may download a copy for private study or non-commercial research. For further reuse terms, see licence terms governing individual outputs. Institutional Repository Policy Statement

\title{
RaY
}

Research at the University of York St John

For more information please contact RaY at ray@yorksj.ac.uk 


\title{
Est. $\mid$ YORK \\ 1841 ST JOHN \\ UNIVERSITY
}

\author{
Professor Julian Stern, York St John University, York YO31 7EX \\ tel 01904 876520, email j.stern@yorksj.ac.uk, web www.yorksj.ac.uk
Rachel Shillitoe, Research Fellow, York St John University, York YO31 7EX email r.shillitoe@yorksj.ac.uk

\section{Prayer Spaces in Schools: A Subversion of Policy Implementation?}

\begin{abstract}
Based on a major evaluation project, this article presents an emerging theme from research on the activities supported by Prayer Spaces in Schools, an organisation supporting 'pop-up' prayer spaces in schools across the UK and internationally. Evaluating the activities primarily in terms of their possible contribution to spiritual developmenti, a number of important issues arose relating to policy on education and religion. This article focuses on how some engage with these prayer spaces as a way of reimagining and renegotiating educational policy. Based on data gathered from interviews with staff and students (aged 7-16) across seven schools in England, questionnaire responses from 555 students across fifteen schools and feedback from two prayer spaces conferences, a hermeneutic approach is used to compare the interpretations of staff with those of students and the implicit positions of policy documents. This article explores various forms of policy implementation and how staff engagement with prayer spaces can be seen as a form of subversion, with staff tactically subverting policy implementation sometimes in order to promote the very intention of those policies - a form of what we refer to as subversive obedience.
\end{abstract}

\section{Keywords}

prayer, worship, spiritual development, subversion, policy 


\section{Introduction}

\section{it was startling what questions a lot of them came up with}

(Adult in a primary school)

Education policy and practice with respect to religion and spirituality in general, and spiritual development, religious education (RE) and worship in particular, are contentious, and they present challenges to researchers too (Chater and Erricker 2012, Conroy et al, 2013, Schweitzer and Boschki 2018). An evaluation project looking at prayer spaces in schools sits right in the middle of these challenges, and illuminates them. This article explores how a particular initiative provided surprising insights into policy implementation, theorised in part as a form of 'subversive obedience'. The evaluation project (Author1 and Author2 2018), commissioned and funded by the Prayer Spaces in Schools organisation, focused on the contribution of such prayer spaces (i.e. activities in schools that were supported by - although not run or staffed by - the Prayer Spaces in Schoolsii organisation) to the spiritual development of young people (Author1 2009). Although policy - whether on spiritual development or other aspects of schooling related to religion - was not being studied, a number of respondents commented on policy issues. From these comments, this article has been built.

Prayer spaces are temporary 'pop-up' events (perhaps for one or two weeks of the school year) set up, typically, in a school classroom, with various activities - mostly led by children and young people - that 'enable children and young people, of all faiths and none, to explore ... life questions, spirituality and faith in a safe, creative and interactive way' (https://www. prayerspacesinschools.com/). There is 'a range of creative activities that encourage personal reflection on issues such as forgiveness, injustice, thankfulness, big questions, identity and stillness', and the prayer spaces are 'run by a trained team of local Christians from a church or an organisation as a service to the school' (Phil Togwell, leader of Prayer Spaces in Schools, personal correspondence 2018) iii. The activities may include 'prayer walls', 'thankful play dough', 'fizzy forgiveness', 'forgiveness stones', 'letting go', 'name that feeling', 'mirrors', and 'cardboard home' (from the 'top ten' prayer activities, at https://www.prayerspacesinschools.com/topten, with detailed descriptions of the activities available on that site). Such activities have been used in different ways in schools, over many years, and exemplify the history of 'experiential' work in RE (as in Hammond et al 1990) and spiritual development (as in West-Burnham and Huws Jones 2007). In evaluating the contribution of prayer spaces to spiritual development, the approach to spirituality is one described as 'relational', connected to the work of David Hay on 'relational consciousness' (Hay 2007, p 14, and Hay with Nye 2006) and to the advice given by various UK-based curriculum and inspection bodies (with influence in England) such as the work on children's 'relationships with one another, with the natural world, and with God' (QCA 2004, p 14) along with '[a]n awareness of oneself' and '[r]ecognising and valuing the worth of each individual' (SCAA 1995, p 3-4). This approach is summarised in a working definition of spiritual development as helping to enhance relationships with (a) the self, (b) with other people, (c) with the world (in constituent parts or as a whole), and, as appropriate, (d) with the sacred and divine (Author1 2009, p 1-21).

\section{The Study}

In carrying out the evaluation, two linked research tools were used. One was a questionnaire offered to students ${ }^{\text {iv }}$ in all schools involved with Prayer Spaces during 
2016-2017. 555 students aged 7-16 in 24 schools $^{\vee}$ completed questionnaires, answering questions on themselves and on their experiences in the prayer space: 'meeting and thinking about people', conversations carried on 'in your head or out loud', new thoughts or feelings or insights, other ways they have changed as a result of visiting the prayer space, what the best thing was about the prayer space, and how the prayer space could be made better. The second tool used was a semi-structured interview: 71 students and 15 staff in seven schools were interviewed. A brief questionnaire was also completed by 26 participants in two Prayer Spaces in Schools conferences where an Interim Report (based on analysis of about half the data) was presented by the authors (Author1 and Author2 2017). The focus of this article is on how staff engage with prayer spaces as a way of reimagining and renegotiating educational policy related to schools and religion. A hermeneutic approach is used to explore the interpretations of staff and students and their relationship to the implicit positions of policy documents. Using data which foregrounds agency, we explore various forms of policy implementation and how staff engagement in policy implementation can be seen as a form of subversion. There is a range of motivations to take part in prayer spaces, both 'push' motivations (from the Prayer Spaces in Schools organisation itself, and from other Christian organisations who set up prayer spaces) and 'pull' motivations (from those in schools wanting to be involved). In this article, aspects of the work of those in schools is framed as a form of subversive obedience, informed by de Certeau's concept of 'strategies' and 'tactics' (de Certeau 1984, p xix), and by the idea of school staff as 'street-level bureaucrats' (Lipsky 2010). The school staff interviewed were positive about the contribution of prayer spaces to spiritual development, but they also described anxieties - not only related to policy implementation, but also the use and interpretation (by students and their parents, and also by school staff) of the prayer spaces themselves - revealing underlying tensions teachers can face when making space for religion in everyday school life (with similar issues for university life, Su 2018).

\section{Policy Contexts}

There are three policy contexts of particular relevance to prayer spaces in England: the policies on spiritual development, on RE, and on collective worship in schools. All three relate to how schools and religion interact (Author1 2007, 2017), and so any analysis of a school activity such as 'prayer spaces' is likely to raise issues related to those policies. A brief account is given here, with further analysis in Watson 2004, 2007, Author1 2009, and Author1 2018 chapter 8 on spiritual development, Hull 1975, Felderhof 1999, Gill 2004, and Mogra 2016 on collective worship, and Hyde 2006, Parker and Freathy 2011, Parker et al 2016, and Author1 2018 on RE. Policies on all three aspects of schooling were established in England as statutory requirements in state schools (covering schools of a religious character and those now referred to as 'community schools') by the 1944 Education Actvi, and all have been affirmed in subsequent Acts, notably the 1988 Education Act which made explicit the requirement for worship to be predominantly Christian and for spiritual development to be promoted across the curriculum. The most controversial of the three is the requirement to start every school day 'with collective worship on the part of all pupils in attendance at the school' (section 25), although that provision and the requirement to provide RE (referred to as 'religious instruction' in the 1944 Act) also allows for parents to withdraw their children from such activities. That option to withdraw from both worship and RE suggests a stronger link between RE and collective worship than might be expected in some other jurisdictions, as does the legal requirement (for all state schools including those of a religious character and community schools) to involve religious organisations in the production of RE syllabuses. (Spiritual development has no right of withdrawal, and has no legal requirement to involve religious organisations.) Government advice 
on collective worship says that it 'must be wholly or mainly of a broadly Christian character, though not distinctive of any particular Christian denomination' (DfE 1994, $p$ 1), and that being 'broadly Christian' means that it must 'contain some elements which relate specifically to the traditions of Christian belief and which accord a special status to Jesus Christ' (DfE 1994, p 21). John Hull, one of the most influential researchers on both RE and collective worship, suggested replacing the act of collective worship: '[s]chools', he says, 'should be required to hold acts of collective spirituality' (Hull 1995, p 69). He continues:

This expression would remove the controversies, the embarrassments and the divisions at a stroke. The link between spirituality and school assembly would be restored, and there would be an appropriate focus for the quest for spirituality which is being pursued so vigorously at the present time in the rest of the curriculum. (Hull 1995, p 69.)

Hull's recommendation complements Richard Cheetham's research on teacher attitudes to collective worship. Cheetham identified four main themes that featured in teachers' attitudes towards collective worship: 'inclusivity' (or 'that unity thing'), the 'individual thing' (freedom of choice and personal integrity), seeing collective worship as an 'act of collective responsibility' or spirituality, and the 'desire for inclusivity' that encouraged a focus on common moral values (Cheetham 2000, p 73-79). Moving from collective worship as 'a hymn, a prayer and a rollicking' (Sedgwick 2006, p xi) to moral exhortation, via various forms of spiritual and religious engagement, it is clear how unclear the practice and advice is on this aspect of schooling. Authors such as Felderhof (1999) disagree with Hull's views on what worship is, as well as with his views on the policy requirement of collective worship (which Felderhof supports). Notwithstanding government advice on what 'worship' means (about which Hull 1989 is particularly scornful), the practice itself rarely follows that advice and is often - as Cheetham says - general-purpose, inclusive and somewhat morally-encouraging. This has also been found by Smith and Smith (2013) who noted that the main focus of assemblies now was to promote values and virtues rather than any explicit sense of religious worship.

Spiritual development has languished even more than collective worship, as it is an educational theme that is intended to infuse the whole curriculum, but such evidence as there is suggests, instead, that it is often ignored altogether. Positive examples are provided by Casson et al 2017 , but there is less evidence of the systematic implementation of the policy across all schools. There is also evidence that it is understood quite differently by those required to implement it (whether or not they do indeed implement it) (Davies 1998). McBay, in a critique of prayer spaces, refers to spiritual development as 'the modern euphemism for indoctrination' (McBay 2013).

Although RE is differently understood and is taught with varying degrees of engagement by students and teachers (Conroy et al 2013), it is, unlike spiritual development and collective worship, at least an established and recognised activity in most schools. Moving from a subject focused on Christianity, and with a more or less overt intention vii of bringing students into belief, from the 1970s, influenced by the new and broadly phenomenological university discipline of 'religious studies', it developed into a multi-religious subject that, although it still expected a personal response from students, had no such expectation of promoting a particular religion. (How the changes in England compare to those elsewhere in the world is described in Author1 2018, chapter 4.) Different pedagogies have been developed, from the experiential (Hammond et al 1990) and the post-modern (Erricker and Erricker 2000) to the more theological (Wright 1993), but - as for other subjects of the curriculum - RE in 
classrooms is rarely quite like it is expected to be according to statutory syllabuses or academic theories (Conroy et al 2013).

With these three policy fields introduced, this article can move on to consider how staff, and to a lesser extent students, responded to prayer spaces in terms of the relevant policies - noting that prayer spaces themselves are not specifically required by any of the statutory policies or government advice on their implementation.

\section{Encountering Religion and Spirituality in Prayer Spaces}

In terms of the four dimensions of spiritual development, students reported on the contribution of prayer spaces to all dimensions (see Author1 and Author2 2018 for full questionnaire, findings and analysis). Responses, summarised in Table 1, were coded in line with the four categories of spirituality as outlined in the introduction: self, other people, world and the sacred and divine. Responses that were coded as 'self' included any reference to self-reflection (e.g. 'How I can be a better person in the future'), responses that directly referenced other people such as family members or friends were coded as 'other people', the world code was attached to responses referring to animals, manufactured objects, nature, and the world as a wholeviii and any references to God, spirits or higher powers were coded as sacred and divine.

\begin{tabular}{|c|c|c|c|c|}
\hline & $\begin{array}{l}\% \text { Self } \\
(N=10)\end{array}$ & $\begin{array}{l}\text { \% Other } \\
\text { People } \\
(N=70)\end{array}$ & $\begin{array}{l}\text { \% World } \\
(N=16)\end{array}$ & $\begin{array}{l}\% \text { Sacred } \\
\text { and } \\
\text { Divine } \\
(N=31)\end{array}$ \\
\hline \multirow{2}{*}{$\begin{array}{l}\text { Meeting and thinking about people. } \\
\text { These are the people I met or } \\
\text { thought about: }\end{array}$} & 8 & 55 & 16 & 24 \\
\hline & $\begin{array}{l}\% \text { Self } \\
(N=33)\end{array}$ & $\begin{array}{l}\% \text { Other } \\
\text { People } \\
(N=73)\end{array}$ & $\begin{array}{l}\% \text { World } \\
(N=16)\end{array}$ & $\begin{array}{l}\% \text { Sacred } \\
\text { and } \\
\text { Divine } \\
(N=11)\end{array}$ \\
\hline \multirow{2}{*}{$\begin{array}{l}\text { When you met or thought about } \\
\text { people, in the prayer space, what } \\
\text { were you thinking about? This is } \\
\text { what I was thinking about: }\end{array}$} & 25 & 55 & 12 & 8 \\
\hline & $\begin{array}{l}\% \text { Self } \\
(N=20)\end{array}$ & $\begin{array}{l}\% \text { Other } \\
\text { People } \\
(N=50)\end{array}$ & $\begin{array}{l}\% \text { World } \\
(N=3)\end{array}$ & $\begin{array}{l}\% \text { Sacred } \\
\text { and } \\
\text { Divine } \\
(N=16)\end{array}$ \\
\hline \multirow{2}{*}{$\begin{array}{l}\text { Can you describe any conversations } \\
\text { (in your head or out loud) that you } \\
\text { had when you were involved in the } \\
\text { prayer space? This is how the } \\
\text { conversation went: }\end{array}$} & 22 & 56 & 3 & 18 \\
\hline & $\begin{array}{l}\% \text { Self } \\
(N=47)\end{array}$ & $\begin{array}{l}\text { \% Other } \\
\text { People } \\
(N=27)\end{array}$ & $\begin{array}{l}\% \text { World } \\
(N=3)\end{array}$ & $\begin{array}{l}\% \text { Sacred } \\
\text { and } \\
\text { Divine } \\
(N=8)\end{array}$ \\
\hline $\begin{array}{l}\text { Can you describe any new thoughts } \\
\text { or feelings or insights you had, any } \\
\text { new ideas, when involved in the } \\
\text { prayer space? These were my new }\end{array}$ & 55 & 32 & 3 & 9 \\
\hline
\end{tabular}




\section{Table 1: Data from questionnaire}

Overall, $46 \%$ of responses to all questions referred to the self and when asked what 'the best thing was' about the prayer space, $88 \%$ of responses referred to the activities that were primarily self-reflective. The second most common category of response referred to other people ( $35 \%$ of responses). $8 \%$ of responses referred to 'the world', $11 \%$ of responses overall mention referred to sacred and divine, and only $1 \%$ of students mentioned the sacred or divine in response to a question on 'the best thing' about the prayer spaces. Almost a quarter of students $(24 \%$ of those answering the question) mentioned the sacred and divine in response to 'these are the people I met or thought about', and $18 \%$ of students (of those answering the question) mentioned the sacred or divine in response to 'can you describe any conversations (in your head or out loud) that you had when you were involved in the prayer space'. This may on first appearance seem surprising, however as will be discussed later, many of the participants when interviewed about prayer spaces discussed the flexible and individual nature of these events, allowing them the freedom to create their own meaning which transgressed religious and nonreligious boundaries. In sum, a small proportion of students mention the sacred or divine in a questionnaire about prayer spaces. However, no question directly asked students to respond about God, the sacred of the divine (see Author1 and Author2 2018 for full list of questions). The relatively small number of responses referring to God or another higher power is worth noting, as almost half of the students self-identified as belonging to a religious group (40.4\% Christian, 5.4\% Muslim, Hindu, Sikh or Jewish). It is the relationship of views on religion to policy on education and religion that is at the core of this article and will be discussed in the following section

\section{Forced prayer or self-reflection? Balancing structure and agency in Prayer Space}

Prayer and worship are intimately connected, with definitions of each often referring to the other (Bowker 1997, interlinked through 'praise' in particular), and they are interrelated in school practice over many years. However, notwithstanding the legal requirement for school worship, the expectation of prayer in prayer spaces was regarded as particularly challenging. One teacher said:

I guess it is kind of well yes, it is kind of forced prayer - but at the same time it's good in the sense that ... if you're not really that religious at home ... it kind of gives them the opportunity to take part and actually reflect on their own lives

It is 'kind of forced prayer' but 'it's good' - not so much as prayer but as 'self-reflection'. The teacher went on to say that 'on introspection and just contemplating your own life ... you don't get a lot of opportunity to do that sort of in this day and age having that opportunity where you literally get five minutes to think about your own thoughts'. Engaging with the prayer space, the teacher concluded, is

quite meditative almost essentially it's like a form of meditation which I thought was really good because I'm quite big into meditation and how good it is for your wellbeing just taking ten minutes out of the day to relax and kind of breathe and think about things I think that definitely helped with that

'Forced prayer' now becomes a more acceptable form of 'meditation' and 'selfreflection'. In this way the teacher seems to have negotiated and reconstructed an 
understanding of prayer to one that includes meditation and self-reflection, and with this, a greater sense of agency on the part of students in that they have 'five minutes to think about your own thoughts'. In the following case, one teacher reflected that nonreligious students could be divided into two groups: those who were happy to try 'praying to God' (as a 'novelty'), and those who objected to the activity.

The kids who aren't religious went into two brackets. They either really loved it so they were at times was completely novel and they want to kind of reflect and think 'oh yes this is fun praying to God' and stuff. Then you had the other kids who were more disengaged because they are like, 'I don't believe in God why am I here?'

It is interesting that these comments are said of prayer spaces by adults (both teachers), whilst the adults seemed unaware of - or did not think it worth mentioning the legal requirement to start every day with an act of collective worship - a genuinely (legally) 'forced' experiential worship activity. The following adult contrasts the 'experiential' character of prayer spaces with the presumably non-experiential RE lessons, with no mention at all of collective worship.

For me - in RS [Religious Studies - the name of the GCSE public examination subject usually taken at 16] or RE, kids are taught about religion, and the prayer space ... allows them to practice something of whatever they choose to believe. So it allows freedom of practice - ... every other lesson ... will 'teach you about it', ... [whereas] we are going to 'practice' and we are going 'to do a bit of it'.

Thinking about prayer spaces in relation to sociological discussion of structure and agency, allows us to consider the ways in which teachers and students are attempting to bridge the gap between structure and agency. We can observe the participants' recognition of the wider structures around them, such as policy requirements for collective worship and RE, and the constraints and limits this may impose on students. Prayer spaces can be seen as allowing students and teachers to create their own meaning and practice and interpret the various activities within prayer spaces. As the adult above comments, a prayer space 'allows freedom of practice'. If we think of prayer spaces in terms of Giddens' (1984) structuration theory, we can observe how these events both constrain and enable individual agency. Prayer spaces exert influence over participants' agency due to the ways the practice within the events are facilitated and structured. However, they also enable agency by the way adults can facilitate such exercises in order to encourage individual meaning-making and interpretation. We can see this bridging or balancing of structure and agency earlier when a teacher remarked that prayer spaces were 'kind of forced prayer', but later went on to discuss the meditative and relaxing qualities of prayer space. It is important to note, however, that such balancing will depend upon how prayer spaces are enacted in each school. It is this active construction and reconstruction of the space (by teachers and by students) that allow us to think of prayer spaces in terms of the interrelationship between structure and agency (Giddens 1984).

\section{Creating Space for Non-Christian Prayer}

When reflecting on the ways in which meaning is made and remade during prayer space events, the experiences of non-religious and non-Christian students were particularly interesting in terms of how they negotiate the requirements of prayer space. One student was ambivalent about the experience, seeing the activity as not always religious: 'I didn't really necessarily think about it as being like totally religious'. The prayer space was described as 'helping you think about your beliefs' rather than requiring you to compromise a non-religious position. Yet the student also noted that 
'some things were obviously' religious. This student's reflection on prayer also reveals the ambiguous nature of prayer. It is not always treated as an exclusively religious practice, reflecting sociological research on the highly complex and nuanced nature of prayer in contemporary society which can transgress more simplistic definitions (Giordan and Woodhead 2015). Previous research on the experience of prayer for nonreligous students has highlighted the diverse array of tactics and meaning children create in such spaces (Hemming 2015, 2017, Author2 2018). Hemming (2015) discovered how children used their bodies to subvert and resist the prayer strategies of the school by keeping their eyes open during moments of prayer, making the sign of the cross quickly during meal times or recrafting the words of the prayer to meet the needs of their own spiritual or religious beliefs. Author2 (2018) similarly found how nonreligious children exercised their agency during moments of prayer in collective worship by using this occasion to speak to deceased relatives or pets. Hemming (2017) also found both religious and nonreligious children spoke positively about prayer, noting its calming and relaxing effect, while also finding that some children still found the experience boring and repetitive.

This sense of simultaneously moving towards and away from more 'religious' interpretations of prayer spaces is given a further twist by the teacher who refers to how the school - over several years of running prayer spaces - had gradually taken Jesus out of the activities.

[Interviewer: Is there mention of Jesus or God ... in the materials or something else that would identify - ] Teacher: It used to be yes. ... It was like very much Jesus ... but ... it's really evolved I mean we talk about prayer we talk about thought we talk about ... spirituality, but not 'this is Christian'. It might say 'ask God a question' or 'if you could write to God what would your letter be', but it's not overtly Christian.

Another teacher, similarly, said this:

I don't think our children associated [the prayer space] with a particular religion. ... I think they did associate certainly some of the activities with God, [or] rather an idea God and a supreme being, but ... I don't think any of them came away thinking oh that was about Jesus or Christianity or any... particular religion.

One of the participants in the Prayer Spaces in Schools conference was 'taken aback by the comment ... by one adult, "it was very much Jesus but ... it's really evolved", but this movement away from the explicitly Christian was a common theme. One teacher said that the organiser - someone external to the school, trained by Prayer Spaces in Schools - was 'very very clear about the fact that it's not Christian, it's actually about thinking'. That teacher also said 'I don't see it as being religious: I see it as spiritual':

We recognise that there is a spiritual dimension to life, and it's a dimension in our society for all sorts of reasons and in all sorts of backgrounds. It isn't explored at home ... We would like to [do] more at school but actually there isn't time, and I think it's also an area that I think staff are sometimes ... uncomfortable

Another teacher talks about crossing religious boundaries and the boundaries between religion and non-religion:

The religious ... aspect of it crosses religion: ... [it] is really important that it goes beyond the boundaries of one particular faith. ... Our counsellor, who is not a Christian at all, ... says that [the prayer space] is a really valuable space for mindfulness, which ... has ... Eastern religio[us] bases 
Another teacher said of the students taking part in prayer spaces that 'some, you could tell, ... really benefitted from that mindfulix relaxing type thing'. Later in the interview, the same teacher explained the task of 'making sure I didn't think it was too religious', by 'mak[ing] sure the focus is on ... them learning about themselves and being mindful'. The prayer space had 'a nice balance' as 'I don't think there was too much religion in it'. Yet many of the teachers recognise the discomfort of some non-Christian students.

I think some of them find it quite ... challenging but they all ... access it. ... If we have got anybody who is feeling uncomfortable about it, we can have conversations about it before. I think we had one child who didn't come in because there was a lot going on in the news and she's a Muslim.

The teacher continued, exploring the personal reasons for the student's discomfort:

She was Year 3 [aged 7-8] and she was feeling anxious about ... her understanding of her own faith and not wanting to do something that wasn't within her faith structure. ... She was just at that age, it was easier for her to stay out of the space.

Nevertheless, this teacher concluded, 'everybody else goes in, ... they all go through the Space'. Wilson (2015) in his research, also discovered a range of responses from Muslim students to Christian prayer. Characterising this as confrontational resistance, non-confrontational active resistance, passive resistance and active acceptance, Wilson was also able to attend to the different modalities that students' agency takes in such occasions and the way students can use their bodies to resist or comply with strategies during prayer assemblies. A teacher in the prayer spaces research noted that 'I guess it's you know it's even though they [i.e. the students] know I guess essentially it's Christian as in like you know we run it at school and we are a Christian school'. But the teacher continued:

but we are actually very open with our pupils: ... they need to form their own opinions, they need to form their own beliefs and that we are actually there to help guide them. ... We can tell them ... what we believe or what's in the Bible but then they actually have to make decisions for themselves. ... Some pupils go [to] church, some pupils don't go to church [and] we've got some Muslims at school and you know we are very open with them to actually discuss and debate it.

Hemming's (2017) research described the tensions of compulsory prayer in schools with children from a range of religious and nonreligious backgrounds. Some of his nonreligious participants found the experience tedious, boring and awkward, in the way it conflicted with their unbelief in God. The way in which participating in religious practices such as prayer were bound up with wider school rules, norms, and expectations created discomfort. Hemming found that students were unware of and confused about their right to opt out of such occasions. In our prayer spaces research, teachers often discussed the strategies they developed in order to encourage individual meaning-making and alleviate potential tensions for children from a non-Christian or nonreligious background. In attending to students' agency, this teacher describes how students were encouraged to create their own meaning and experience out of such occasions:

In prayer space ... we are very open about it, [and] say it's ... a time to sit and reflect and ... question.... This is your time so we are not ... saying you need to think about this, or this is what you should believe. It's ... their time to explore and think. 
A number of teachers argued for 'prayer' to be excluded from the name of the space and, in several instances, from the activities too.

I must say ... I know it's coming from a Christian perspective, but I would much prefer it if it was in terms of personal reflection rather than prayer. I think that immediately turns some of the students off. ... I don't really like pushing them towards any one religious leaning. [Interviewer: Perhaps a way to overcome that would be just to use the word[s] 'personal reflection'?] Yes.

These quotations reveal values akin to liberal individualism, in the sense that it is the individual's rights that should be considered and catered for whilst also considering the wider needs of the group (Madge et al 2014). Religion and prayer are also viewed in terms of choice rather than obligation. Some students described the activities in the same way, for example saying the prayer space 'doesn't really ... specify one religion it's more just spiritual and you can just turn everything in your life and reflect'. Another, though, noted that 'most of the time it is based on a Christian mainly Christian theme'. However, that student continued to say 'the stations themselves aren't exclusively Christian they can be for absolutely anyone to just have time and think about their life and everything that is happening'.

It was a small number of the participants in the Prayer Spaces in Schools conferences who provided the most staunch support for prayer spaces as explicitly Christian. They were asked what should be added to the Interim Report to make the final report most useful to schools and practitioners, and one said: 'That prayer spaces are rooted in Christian faith and relate to the bible, in the end'. Another was surprised by the 'absence of God' in the Interim Report: 'I was expecting God to be included in the conversation'. Clarifying that comment, the respondent continued: 'Clearly this is more of an academic exercise'. Those taking part in the conferences belonged to, or expected to belong to, the 'trained team of local Christians from a church or an organisation' who would run prayer spaces 'as a service to the school' (quoted from the introduction to this article), so such concerns were not surprising. Another conference participant explained it by noting 'volunteers from churches may/will want it to be Christian prayer', adding an awareness of 'the tensions this may cause in community schools'.

In providing this account, the intention is not simply to suggest there are many different interpretations of prayer spaces. Rather, it is to note that many research participants, including both teachers and students, expressed an ambivalence when reflecting on religion and prayer spaces. This ambivalence may be better described as a 'creative ambiguity', a rich ambiguity as described in literary studies since Empson (1961). A number of respondents are straddling the Christian and non-Christian, the religious and non-religious, the religious and the spiritual, the experiential and the (more distanced) educational, or the voluntary and the compulsory. This can be evidence of their anxiety, an anxiety to please everyone (especially colleagues, students and parents), as seen in respondents using phrases like 'I guess it's ... but we are actually ...', or 'I must say ... but I would much prefer it if ...' (quoted above). But it can also - we suggest - be evidence of forms of resistance and the subversion of expectations.

\section{Resistance and Subversion}

The three policy areas discussed in this article are a source of controversy and tension both within education and public debate. Collective worship policy is retained despite being attacked by religious and non-religious groups and despite being ignored by many schools (Cumper and Mawhinney 2015, 2018). Spiritual development is 
understood differently by almost everyone who contributes to policy or its implementation (Priestley 1997, Author1 2009, ch 1 and 6, Author1 2018, ch 8). RE, too, lacks a single clear purpose, not least because of the local determination of statutory syllabuses in England - so that there are more than 150 different descriptions of the subject, each revised every five years (Chater and Erricker 2012). England is unusual internationally $x$ in having such complex and contested policies related to religion and school. Even if other jurisdictions may require other 'collective' activities to start the school day (such as saluting the flag in the USA, or T'ai Chi activities in China), many have holistic approaches to education that incorporate what in the UK is referred to as spiritual development (such as the German principle of educational Bildung), and some have diverse and locally- or regionally-determined RE syllabuses (as in Germany). Yet English policy seems exceptionally conflicted. Many would say that conflict and lack of clarity in policy or its implementation is a problem to be fixed (as in Hull 1989, Castelli and Chater 2018). It is certainly a source of anxiety and perhaps stress for those professionals at the 'front line' of implementing the policies - the 'streetlevel bureaucrats' of Lipsky (2010), described as facing 'dilemmas'. Yet these very conflicts and ambiguities can also be framed as opportunities, as gateways for professional agency, enabling teachers and other school-based professionals to create meaningful activities.

In understanding how schools utilise the resources of Prayer Spaces in Schools while attempting to meet the various educational policies already described, we can appropriate thinking from de Certeau (1984) and consider how such actions are revealing of both compliance and resistance. de Certeau (1984) describes strategies as actions associated with institutions or those in governance whereas tactics are the operations carried out by those who do not possess such power as a way to subvert or reconfigure the regimes of those in authority. By examining everyday practices, de Certeau reveals the various ways in which persons seek to resist the strategies of those that try to oppress them and in doing so, try to create a more democratic way of being. In describing the quotidian lived reality of tactics and strategies and the relationship between them, de Certeau (1984) explains:

Many everyday practices (talking, reading, moving about, shopping, cooking etc.) are tactical in character. And so are, more generally, many 'ways of operating': victories of the 'weak over the strong' (whether the strength be that of powerful people or the violence of things or of an imposed order, etc), clever tricks, knowing how to get away with things, 'hunter's cunning', manoeuvres, polymorphic simulations, joyful discoveries, poetic as well as warlike. (de Certeau 1984, p xix.)

Although schools would be seen as institutions with power and governance, teachers (as power-holders in schools) are also in a position where they need to develop tactics due to the strategies deployed by educational policy (i.e. more powerful external organisations). In this way educational policy is the 'imposed order' as described by de Certeau, and as such provokes tactical responses from those on whom such order is imposed. Such a tactic 'insinuates itself into the other's place, fragmentarily, without taking it over in its entirety, without being able to keep it at a distance' (de Certeau 1984, p xix). However, the teachers' use of tactics as a way to subvert and negotiate educational policy, is not necessarily always representative of non-compliance. For some, their tactical approach to policy implementation demonstrates both compliance and subversion by their way of meeting the legal requirement of collective worship but doing so in a way that subverts some of the apparent strategic motivations of those in power. In this way, schools and classrooms can be the site of compliance and subversion by teachers and students being 'subversive without necessarily being oppositional' (Brogan 2017, p 516). Whereas an act of explicit resistance can in some 
circumstances maintain a system (encouraging the strengthening of the forces maintaining a system), a subversive act can be influential within a system. What seems to be happening with prayer spaces is that a significant number of the teachers who were interviewed were conscious of the conflicts and ambiguities in the three policy areas, and were - albeit with some anxiety - using the prayer spaces as a tactical response to educational policy. Thus, the teachers subverted those aspects of schooling that were seen as, variously, impersonal, performative, anti-religious, narrowly cognitive, or materially-driven. It would be valuable - but beyond the scope of this article - to investigate other ways in which the tensions with respect to policies on religion and schooling, or education policies more generally, may be subverted by teachers.

One of the Prayer Spaces in Schools conference participants said that the most important thing to add to the Interim Report was '[l]inks to current legislation required in schools to show how [prayer spaces] can help schools to cover these demands' (italics in original). One teacher who was interviewed was asked about why it took prayer spaces to implement long-established policies (related to worship or spiritual development), and they responded:

I know exactly where you are coming from. ... I often think that in some ways ... being statutory ... was not a good move, because ... what ... happened ... [was] everybody was obsessed with making sure they had the collective acts of worship every day: ... there was lots of box ticking, ... but not the spirit. I think ... spirituality was the worse for it ... which sounds illogical ... because ... what this [i.e. the prayer space] does is spiritual. ... I'm not sure having an assembly where you make sure they pray every day is ... necessarily the best way of doing it, ... it's not meaningful for the children.

A voluntary process - one in which teachers and students are given their own agency is one that is recommended by this teacher. That is, incidentally, the basis for much of the radical and anarchist educational theory of Neill (1985), Brogan (2017), and Illich (1971). The intention of the policy (on worship or spiritual development) is supported, and the teacher suggests a 'subversive' tactic in order to do what the policy expects. This 'loss of spirituality' due to bureaucratic 'box ticking' approach of policy on spirituality was also echoed by another teacher who spoke of the 'loss' that can occur when adhering to policy demands. 'It's ... the spiritual part ... that gets lost because we live in a world of accountability measures', whereas 'if we are about character development or about giving people inner strength we need to give them a full repertoire'. What can be seen in this response, as in so many others, is that the wish to subvert the 'accountability measures' is achieved through implementing the 'spiritual development' policy. This is not subversion of the whole school system, but a desire to subvert one aspect of policy implementation in order to implement other policies - on spiritual development and, in this case, perhaps character development too (Arthur and Carr 2013). Moving further away from merely implementing policy, another teacher noted the opportunity for prayer spaces to use those outside the school to achieve what the policy might have intended.

Time to set up an effective space I think is really important. ... We work alongside [an organisation of] local Christian schools workers, and our main worker is just about to go to train for ministry, she's a very good friend, she's fab. ... I got them involved with us because she's a friend. It's now become a major part of their mission and the ministry work that they do in schools is running what they called 'think spaces' - so it's less religious-orientated, but basically it's prayer spaces. That is one of the most valuable things - having that support from outside. The kids ... 
feel that they can ... access the space without being judged or without ... feeling 'that teacher thinks I'm that' or 'I don't like that teacher'. ... So they ....know that it's... a safe space and it's a neutral space and they are not going to have any preconceived ideas.

This tactical approach to 'outsourcing' spiritual development at the school was also read in terms of providing more opportunities for children's agency due to the perceived neutrality (at least in the sense of independence from the school/teacher) an 'outsider' would have. Here the teacher was aware of the influence of their own subjective positions on the prayer space. Involving a third party to help facilitate the activities was not only a subversion of educational policy (perhaps an example of delegated subversive obedience, as suggested by a participant in one of the Prayer Spaces in Schools conferences), but also created a new space within school for spiritual development. To have a third party take responsibility for some activities during the school day may also be a welcome reduction in the pressure on teachers to manage all school-time activities, but this was not commented on explicitly by participants in the research. Third party involvement from religious organisations in schools in England can also be regarded as controversial (see McBay 2013), but this was not commented on by participants. When asked what the difference was between collective worship and prayer spaces and why the latter seem to be more warmly received, a teacher reflected that:

Assembly is very formal. ... We've got three hundred people in together and ... we all sing a hymn, and a prayer will be said, and they will answer Amen. Whereas in the prayer space it's about them owning what they are doing. They've got a variety of activities they can choose to access or not access: they can choose to sit quietly and think, they can choose to do something creative or not. So it's that freedom of engagement. Whereas in assembly, this is what you do and this is how you behave.

The distinction, once again, is between a 'forced' policy implementation, and one that involves more agency on the part of students. These policy requirements are particularly revealing of how students' agency is continually negotiated and is historically, culturally, spatially and generationally contingent (Oswell 2013). One aspect of agency is the choice students had over the focus on the sacred and divine in prayer spaces. In the questionnaire evidence (described above), there was evidence of choices made that avoided the sacred and divine, whilst other students mentioned positively the opportunity to focus more on the sacred and divine than was possible in RE:

It's just because in RE I normally find it can get a bit boring. ... I feel like we shouldn't go for a lesson like ... RE ... all the time because ... it ruins the fun. ... I feel like ... if we could be available to go to prayer space then it would help us develop our knowledge with Christ and not our knowledge of like how they teach us other ... religions, ... so we could learn more about our religion.

\section{Conclusion}

How teachers and other school staff tactically subvert various forms of policy implementation, sometimes in order to promote the very intention of those policies, is an original approach to policy studies which, normally, look at subversion as a way of avoiding policy implementation. (It is likely that some adults and students in this research were indeed subverting policy implementation, but the focus in this article is on the idea of subversive obedience.) Prayer spaces are challenging and controversial in a number of ways - not least, we conclude, because they highlight some otherwise 
hidden challenges of English education policy, and policy implementation, with respect to religion. We can also observe that it is not only the staff who negotiate educational policy through subversive practices. Students also tactically reconstruct and produce their own meaning-making through their everyday practices.

As such it is crucial to attend to the agency of students, and the ways in which both students and teachers at times actively try to restructure prayer space in order to create a diverse and inclusive environment. Ambiguous meanings were purposely cultivated and generated during prayer spaces, and enabled those occasions to act as a tools of 'subversive obedience'. Schools were still able to comply with the norms and rules that broader educational policy placed on them, but through their active recrafting of such events and through focusing on individual meaning-making, schools participating in prayer space were able to subvert some of the expectations of educational policy implementation whilst still remaining compliant.

Although this research was based on prayer spaces in English schools, the principles of policy implementation and subversion, and the idea of subversive obedience (or delegated subversive obedience), with respect to education and religion could, in turn, be applied to other contexts. For example, the continuing ambiguities related to RE in many German states where students are taught 'confessionally' with other students of the same religion (Schreiner, in Kuyk et al 2007, Jozsa, in Avest et al 2009), RE in Senegal where teachers tend to 'teach for religion in public schools (in a devotional sense)' rather than, as in Senegal, 'teach about religion (in an academic sense)', notwithstanding the 'official curriculum' (Croché 2015, p 37), or more general issues about policy on education and religion in the USA (Feinberg 2014).

This article provides new insights on policy implementation and subversion ${ }^{\times i}$. Those aspects of schooling that may create anxieties, because of their in-built conflicts or ambiguities, can also - in the case of prayer spaces, we suggest - provide opportunities for subversive tactics that might achieve more to 'implement' the intentions of policies on collective worship, spiritual development, and RE, than the straightforward, non-agentic, implementation of the policies.

\section{Bibliography}

Arthur, J. and Carr, D. 2013. "Character in Learning for Life: A Virtue-Ethical Rationale for Recent Research on Moral and Values Education." Journal of Beliefs \& Values 34(1): 26-35.

Avest, I. ter, Jozsa, D.-P., Knauth, T., Rosón, J. and Skeie, G. (eds). 2009. Dialogue and Conflict on Religion: Studies of Classroom Interaction in European Countries. Münster: Waxmann.

Bowker, J. (ed). 1997. The Oxford Dictionary of World Religions. Oxford: OUP.

Brogan, A. J. 2017. "The Exilic Classroom: Spaces of Subversion.” Journal of Philosophy of Education 51(2): 510-523.

Casson, A., Cooling, T. and Francis, L. J. 2017. Lessons in Spiritual Development: Learning from Leading Christian-Ethos Secondary Schools. London: Church House Publishing.

Castelli, M. and Chater, M. (eds). 2018. We Need to Talk About Religious Education: Manifestos for the Future of RE. London: Jessica Kingsley. 
de Certeau, M. 1984. The Practice of Everyday Life. Berkeley, California: University of California Press.

Chater, M. and Erricker, C. 2012. Does Religious Education Have a Future? Pedagogical and Policy Prospects. London: Routledge.

Cheetham, R. 2000. "Collective Worship: A Window into Contemporary Understandings of the Nature of Religious Belief?" British Journal of Religious Education 22(2): 71-81.

Conroy, J. C., Lundie, D., Davis, R. A., Baumfield, V., Barnes, L. P., Gallagher, T., Lowden, K., Bourque, N. and Wennell, K. 2013. Does Religious Education Work?: A Multi-Dimensional Investigation. London: Bloomsbury.

Croché, S. 2015. "Science and Religion on the Blackboard: Exploring Schoolmasters' Beliefs and Practices in Senegal." British Journal of Religious Education 37(1): 37-52.

Cumper, P. and Mawhinney, A. 2015. Collective Worship and Religious Observance in Schools: An Evaluation of Law and Policy in the UK: An AHRC Network Report.

Bangor: Bangor University, University of Leicester, AHRC.

Cumper, P. and Mawhinney, A. (eds). 2018. Collective Worship and Religious Observance in Schools. Oxford: Peter Lang.

Davies, G. 1998. "What is Spiritual Development? Primary Headteachers' Views." International Journal of Children's Spirituality 3(2): 123-134.

Department for Education (DfE). 1994. Religious Education and Collective Worship: Circular Number 1/94. London: DFE.

Empson, W. 1961. Seven Types of Ambiguity: Third Edition. Harmondsworth: Penguin.

Erricker, C. and Erricker, J. 2000. Reconstructing Religious, Spiritual and Moral Education. London: RoutledgeFarmer.

Feinberg, W. 2014. "An Assessment of Arguments for Teaching Religion in Public Schools in the United States." Religious Education 109(4): 394-405.

Felderhof, M. C. 1999. "On Understanding Worship in School: Part One: On Schooling and Education." Journal of Beliefs \& Values 20(2): 219-230.

Giddens, A. 1984. The Constitution of Society. Berkeley, California: University of California Press.

Gill, J. 2004. "The Act of Collective Worship: Pupils' Perspectives." British Journal of Religious Education 26(2): 185-196.

Giordan, G. and Woodhead, L. (eds). 2015. A Sociology of Prayer. London: Routledge.

Hammond, J., Hay, D., Leech, A., Moxon, J., Netto, B., Robson, K. and Straughier, G. 1990. New Methods in RE Teaching: An Experiential Approach. London: Oliver \& Boyd.

Hay, D. 2007. Why Spirituality is Difficult for Westerners. Exeter: Societas Essays in Political \& Cultural Criticism. 
Hay, D. with Nye, R. 2006. The Spirit of the Child: Revised Edition. London: Jessica Kingsley.

Hemming, P. 2015. Religion in the Primary School: Ethos, Diversity, Citizenship. London: Routledge.

Hemming, P. 2017. "No offence to God but I don't believe in Him': religion, schooling and children's rights." Ethnography and Education 1-18.

Hull, J. M. 1975. School Worship: An Obituary. Norwich: SCM Press.

Hull, J. M. 1989. "School Worship and the 1988 Education Reform Act." British Journal of Religious Education 11(3): 119-125.

Hull, J. M. 1995. “Editorial.” British Journal of Religious Education 17(2): 66-69.

Hyde, B. 2006 “'You can't buy love': Trivialising and the Challenge for Religious Education." Journal of Beliefs \& Values 27(2): 165-176.

Illich, I. D. 1971. Deschooling Society. Harmondsworth, Middlesex: Penguin.

Kuyk, E., Jensen, R., Lankshear, D., Manna, E. L. and Schreiner, P. (eds). 2007. Religious Education in Europe: Situation and Current Trends in Schools. Oslo, Norway: IKO.

Lipsky, M. 2010. Street-Level Bureaucracy: Dilemmas of the Individual in Public Services. New York: Russell Sage Foundation.

McBay, A. 2013. "Prayer Spaces in Schools." National Secular Society: Opinion (online, at https://www.secularism.org.uk/opinion/2013/08/prayer-spaces-in-schools).

Madge, N., Hemming, P. J. and Stenson, K. with Allum, N., Calestani, M., Goodman, A., King, K., Kingston, S. and Webster, C. 2014. Youth On Religion: The Development, Negotiation and Impact of Faith and Non-Faith Identity. Hove, East Sussex: Routledge.

Mogra, I. 2016 "Perceptions of the Value of Collective Worship Amongst Trainee Teachers in England." Journal of Beliefs \& Values 37(2): 172-185.

Neill, A. S. 1985 [1960]. Summerhill: A Radical Approach to Child-Rearing. Harmondsworth: Penguin.

Oswell, D. 2013. The Agency of Children: From Family to Global Human Rights. Cambridge: Cambridge University Press.

Pandya, S. P. 2018. "Prayer Lessons to Promote Happiness Among Kindergarten School Children: A Cross-Country Experimental Study." Religious Education 113(2): 216-230.

Parker, S. G. and Freathy, R. J. K. 2011. "Context, Complexity and Contestation: Birmingham's Agreed Syllabuses for Religious Education since the 1970s." Journal of Beliefs \& Values 32(2): 247-263.

Parker, S. G., Freathy, R. and Doney, J. 2016 "The Professionalisation of Non- 
denominational Religious Education in England: Politics, Organisation and Knowledge." Journal of Beliefs \& Values 37(2): 201-238.

Priestley, J. 1997. "Spirituality, Curriculum and Education." International Journal of Children's Spirituality 2(1): 23-34.

Qualifications and Curriculum Authority (QCA). 2004. Religious Education: The NonStatutory National Framework. London: QCA.

School Curriculum and Assessment Authority (SCAA). 1995. Spiritual and Moral Development: SCAA Discussion Papers: No. 3. London: SCAA.

Schweitzer, F. and Boschki, R. (eds) 2018. Researching Religious Education: Classroom Processes and Outcomes. Münster, Germany: Waxmann.

Sedgwick, F. 2006. 100 Ideas for Primary Assemblies. London: Continuum.

Smith, G. and Smith, S. 2013. "From Values To Virtues: An Investigation into the Ethical Content of English Primary School Assemblies." British Journal of Religious Education 35(1): 5-19.

Su, F. 2018. "'Place', 'Space' and 'Dialogue': Conceptualising Dialogic Spaciality in English Faith-Based Universities." Journal of Beliefs \& Values 1-14.

Training and Development Agency for Schools (TDA). 2008. Professional Standards for Qualified Teacher Status and Requirements for Initial Teacher Training (Revised 2008). London: TDA.

Watson, B. 2004. "Spirituality in British State Education: An Alternative Perspective." Journal of Beliefs \& Values 25(1): 55-62.

Watson, J. 2007 "Spiritual Development: Constructing an Inclusive and Progressive Approach." Journal of Beliefs \& Values 28(2): 125-136.

West-Burnham, J. and Huws Jones, V. 2007. Spiritual and Moral Development in Schools. London: Continuum.

Wilson, T. 2015. Hospitality and Translation: An Exploration of How Muslim Pupils Translate Their Faith in the Context of an Anglican Primary School. Newcastle: Cambridge Scholars Publishing.

Wright, A. 1993. Religious Education in the Secondary School: Prospects for Religious Literacy. London: David Fulton.

\footnotetext{
${ }^{\mathrm{i}}$ Other possible frameworks considered were the contribution of prayer spaces to achievement in religious education, or to religious engagement. Pandya 2018 presents an evaluation of the contribution of prayer activities to young children's happiness, and this would have been another possible framework. Spiritual development was chosen by those commissioning the research as the most valuable and most viable of the alternatives.

ii The phrase 'prayer space' (using lower case letters and not italicised) refers to those activities organised in schools that were explicitly supported by the Prayer Spaces in Schools organisation. The capitalised and italicised Prayer Spaces in Schools (or Prayer Spaces) refers to the organisation (http://www.prayerspacesinschools.com/).

iii Some schools 'take over' the running of prayer spaces from those who originally set them up, once the structures and activities are familiar.

iv The term 'student' is used to refer to all pupils/students in schools, aged 7-16.

${ }^{v}$ Several hundred UK schools were involved with the organisation in 2016-2017, organising over 500 prayer spaces (with some schools setting up more than one prayer space). The sample of schools who took part therefore represent less than $10 \%$ of that total. However, the sample includes primary and secondary schools, schools with and without
} 
church foundations, and schools in the North and South of the country, roughly representing the spread of schools involved in prayer spaces activities.

vi http://www.legislation.gov.uk/ukpga/Geo6/7-8/31/contents/enacted

vii The 'intention' of a policy is not easy to determine, and the intentions of those who create a policy or who maintain (or fail to overturn) an old policy are even harder to determine. The intentions of lawmakers are sometimes used to justify later interpretations of laws, but intentions are still open to varied interpretations. Throughout this article, putative intentions are ascribed loosely to policies and laws, although, for reasons of space, the word 'putative' or 'apparent' is not generally used, as the focus is on school-level actions.

viii These figures exclude non-responses and negatively- or neutrally-framed responses, e.g. 'I can't remember', 'I didn't have a conversation', or 'not sure'.

ix How 'religious' or 'non-religious' mindfulness practice is, is a contentious issue beyond this article.

${ }^{x}$ There are different approaches to these policies and their implementation in other jurisdictions in the UK (i.e. Scotland, Wales and Northern Ireland). The distinctions are not made in this article, and so reference is only made to England.

xi These insights may be applied well beyond religious issues, of course. 